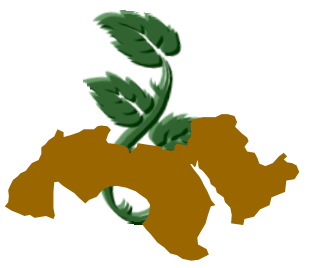

Arab Univ.

J. Agric. Sci., Ain Shams Univ., Cairo, 23(1), 167 - 177, 2015

\title{
IMPACT ANALYSIS OF THE GOVERNMENT POLICIES ON FRUIT AND VEGETABLE SECTOR IN SUDAN IN 2003 AND 2009
}

\author{
Elsayed, E.E,M. Alnagarabi'; A.S. Ahmed ${ }^{2}$ and E.A. Mohamed ${ }^{1}$ \\ 1- Department of Agricultural Economics, Faculty of Agricultural Sciences, University of \\ Gezira, Wad Medani, Sudan \\ 2- Ministry of Agricultural, Gezira State, Wad Medani, Sudan
}

Keywords: Government; Policies; Policy analysis matrix (PAM)

\begin{abstract}
The main objective of this paper was to analyze the impact of government policies on fruit and vegetable sector in 2003 and 2009 in terms of profitability, protection, efficiency, competitiveness and comparative advantages. The study depended on secondary data and information collected from relevant sources and references. The policy analysis matrix (PAM) adopted as an analytical model to achieve the study objective. Private profitability, social profitability, nominal protection coefficient on outputs, nominal protection coefficient on inputs, effective protection coefficient, domestic resources coefficient private cost ratio and subsidy ratio to producer were calculated for the crops under study. The study results show that fruit and vegetable sector was taxed for outputs and subsidized for inputs, the net effect of outputs taxation and inputs subsidies resulted in a net taxation on value added at varying degrees. Consequently, it could be concluded that, although the overall impact was negative and tending to be worse, but the study results indicate that there are still comparative advantages in fruit and vegetable crops production. The study recommended further vertical and horizontal expansion of fruits and vegetables, strengthening production infrastructures, and government should enact efficient policies that correct the distorting tradable - outputs policy.
\end{abstract}

\section{INTRODUCTION}

The horticultural exports performance were very weak. It amounted during 1993 - 2009 an average of about $\$ 2.3$ million constituted $0.6 \%$ of the total Sudanese exports earnings. The total area under the horticultural products amounted to about 0.8 million fed in 1997 (Ahmed, 2000) this area represents only about $2 \%$ of the total area under the agricultural cultivation, which amounted to about 38.2 million feddan during the same year and about $0.4 \%$ of the total arable area (Elsaied, 2000). Regarding the total output of the same period, the Sudanese horticultural sub-sector produces about 5 Million tons or $44 \%$ of the total agricultural production, which was estimated at 11.3 million tons (AOAD, 1998). Based on the above, the Sudanese horticultural sub-sector remained small in terms of area, output and exports, despite the huge endowments of suitable production resources and vicinity to promising foreign markets. Thus, Sudan possesses huge arable land in addition to the plenty water resources and diversified climatic conditions that allow producing a variety of horticultural products in times considered off season for other producing and competitive countries. Moreover, Sudan lies in a close location to promising Arab markets for horticultural crops. However, the Sudanese horticultural sub-sector failed to utilize these opportunities because of many reasons, including the production, post harvest operations and marketing difficulties, as well as, policy induced obstacles. Thus, the horticultural production and marketing are quantitatively and qualitatively hindered, that can be due to a large extent to the inefficient production technologies, the lack of production infrastructures, deficiency of inputs, inappropriate export, ineffective marketing systems and inappropriate economic policies. In spite of the sizable availability of the required resources for the agricultural exports in Sudan, the share of the horticultural exports to the total receipts of foreign 
currencies is very low. This can be attributed to many problems related to technical and economic difficulties affecting the production, marketing and export of the horticultural products. This paper attempts to study the policy oriented aspects that contributed to hinder the expansion of horticultural exports. Scanning the available information on adopting economic policies reveals the bias of implementing strategies towards the agricultural sector in general (Eldaw, 1999). Most of these strategies assigned high priority to expanding the Sudanese agricultural exports The Sudanese government has been widely adopted the structural adjustment programs in 1992. According to Alnagarabi (1997), the main elements of which were:

1. Reduction of export taxes for agricultural exports to $5 \%$ of all crops except cotton and gum Arabic, for which export taxes reduced by $10 \%$.

2. Removing subsidies on inputs, for most important of which are fertilizers, pesticides, land and water.

3. Lifting of price controls and regulations on commodities imposed by the government, with the exception of wheat where the government intervention maintained by determining minimum procurement prices.

4. Reduction of food price subsidies.

5. Abolishing of public market companies monopoly.

6. Shifting from public to private finance

7. Privatization of Agricultural Corporations

The central work of this paper was an attempt to construct a policy analysis matrix (PAM) for the purpose of assessing the impact of government policies on vegetables and fruits in Sudan in 2003 and 2009 and to communicate to policy-makers.

\section{Research methodology}

This paper depended mainly on secondary data, obtained from the annual reports of the Sudanese federal ministries, bank of Sudan, Khartoum airport, the general administration of customs, the Arab organization of the agricultural development year book for agricultural statistics, in addition to various traditional and electronic sources and references. Moreover, the research depended on a limited amount of primary data, through frequent visits to many exporters and Khartoum central market for fruits and vegetables. The collected data and information covered the period 2003 and 2009.Policy analysis matrix was adopted as an analytical matrix and PAM indicators have been estimated and interpreted. Crops selected for PAM analysis include four crops classified as fruits (Mango, Banana ,Date and Lemon) and four crops classified as vegetables (Onion, Green beans, Melon and Okra).

\section{Methodology}

The paper employed the PAM approach in the following steps. First construct a farm budget, which assesses the revenues and costs of every fruit and vegetable crop included in the study. Divide the agricultural inputs into tradable inputs and domestic factors. This disaggregation is useful as it allows the assessment of policies concerning trade in intermediate inputs and those targeting the supply of domestic factors. Then a double rows bookkeeping is taking place. Market prices are used to estimate farmers' revenues, costs and profitability (i.e. private prices). The second valuation of the agricultural activity is at social prices. For example, cost figures in this row are the real costs related to the use of inputs in agriculture which may include policy interventions. A third row is used to determine the difference between the entries in each column. If social prices are lower than private prices (or social costs are higher than private costs) it means that some kind of government support is present. Accordingly, the opposite implies that a produce tax is levied.

\section{Policy analysis matrix structure}

Table (1) explains the main elements of PAM structure.

Table 1. The policy analysis matrix (PAM) structure

\begin{tabular}{|lcccc|}
\hline \multirow{2}{*}{ Revenues } & \multicolumn{2}{c}{ Costs } & Profits \\
\cline { 2 - 4 } & & $\begin{array}{c}\text { Tradable } \\
\text { Inputs }\end{array}$ & $\begin{array}{c}\text { Domestic } \\
\text { Factors }\end{array}$ & \\
\hline Private prices & $\mathrm{A}$ & $\mathrm{B}$ & $\mathrm{C}$ & $\mathrm{D}$ \\
Social prices & $\mathrm{E}$ & $\mathrm{F}$ & $\mathrm{G}$ & $\mathrm{H}$ \\
Divergences & $\mathrm{I}$ & $\mathrm{J}$ & $\mathrm{K}$ & $\mathrm{L}$ \\
\hline
\end{tabular}

Source: Person and Monke (1989).

Where as: The symbols (capital letters) are defined as follows:

A Revenues of outputs at private prices (outputs prevailing actual returns).

B Costs of tradable inputs (such as fertilizers, seeds, plastic mulch, etc.) at private prices. 
C Costs of domestic factors (such as labor, capital, etc.) at private prices.

D Private profits.

H Social profits.

E Revenues in social prices (economic, efficiency or shadow prices adjusted to government interventions).

F Costs of tradable inputs (such as fertilizers, seeds, plastic mulch, etc.) at social prices.

G Costs of domestic factors such as (labor, capital, etc.) at social prices.

Thus, the matrix is made up by the following identities:

Private Profits $(P P) D=A-B-C$

Social Profits (SP) $H=E-F-G$

Output Transfers (I) I = A-E

Input Transfers $(\mathrm{J}) \mathrm{J}=\mathrm{B}-\mathrm{F}$

Factor Transfers (K) $\mathrm{K}=\mathrm{C}-\mathrm{G}$

Total net policy effect (NPE), L=I-J-K

\section{Data}

Farm crop-specific budgets are constructed from recent available data. These are the most updated and detailed estimates of costs and expected grower prices available. For private revenue, we multiply expected yields by grower price. For social revenues we do the following. First we compute a reference world price for each crop. This price represents the lowest possible price available for importing goods of similar quality to substitute for domestic production (the reference price is calculated at the growers' price level. Then we multiply expected yields by the lower figure between the reference price and the grower price for each crop, as this is the lowest price available. For example, if the reference world price is the lower of the two then it is also the social price and it means that import should take place. In any case, if we observe that $A>E$ it implies that there is a binding tax because domestic prices are higher than world prices.

The basic unit in our analysis is one cultivated feddan.

\section{Absolute measures}

The absolute measures are used mainly to evaluate the private profitability (PP) and social profitability (SP).

\section{Private (financial) profitability (PP)}

This type of absolute measures is used in determining the allocation of resources among competing crops. It is computed by the equation; PP = A-B-C (Elamin, 1999).

Private profitability calculations show the agricultural system competitiveness, given in a current technology, output values, input costs and policy transfer. Positive private profits (when $D>0$ ) are indication of super-normal return that may lead to further expansion of the system, Positive values for profits at prevailing market prices confirms the business profit and provides stimulus for existing firms to increase output and for other firms to enter the business. Expansion of existing firms as well as the entry of new firms in the market stimulates economic growth. When the inputs or output prices, are distorted by either market failures, taxes or subsidies, then private profits alone could provide misleading signals (Atif, 1999). While, negative private profits (when $D<0$ ) means that the operators are earning a subnormal rate of return and thus, they will be expected to exit from this activity unless some changes take place to increase the profit to normal level $(D=0)$. From the governmental point of view, all taxes and other forms of transfers are excluded, since they are merely transfer payments (Elamin, 1999).

\section{Social (economic) profitability (SP)}

Social (economic) profitability can be calculated by the equation: SP = E-F-G. A divergence between private and economic profits reveals in absolute terms the deviation of efficient allocation of resources from that favored by the adopted government policies. A crop with high economic and low private profitability implies that the government policies are disfavoring its production, (Jansen, 1986).

The social profit is a measure used to determine the profit of a whole system horizontally at social prices.. Social profit is an efficiency measure as both outputs and inputs valued at prices that reflect scarcity. Positive social profits $(\mathrm{H})$ indicate that, there is a positive social output valuation, which is an incentive for activity expansion under consideration (Atif, 1999). 


\section{The relative measures}

The relative measures are usually used to evaluate both relative competitiveness and relative protection for any crop.

\section{Nominal protection coefficient on outputs (NPCO)}

The NPCO essentially expresses divergences between social and private values as ratios rather than the absolute values, thus facilitating crosssystem comparisons (Gregory, 1995). The objective of NPCO calculation is to measure the actual divergences or distortions between domestic prices and international or border prices of output. (FAO, 1987) reported that, the ratio of NPCO measures the extent of the policy intervention on the output, it can be estimated by NPCO = A / E. Therefore, when its value is less than one, it shows the presence of taxes (tariffs) on the outputs. On the other hand, when its value is greater than one, it indicates the presence of subsidies on outputs. Further, when it is equal or close to one (in the absence of market failure) it reveals the absence of government intervention in the output market (Atif, 1999).

\section{Nominal protection coefficient on inputs (NPCI)}

The NPCl measures the extent of policy intervention on the tradable input. It can be calculated by dividing the tradable input value at private prices (B) by the tradable input value at social prices $(\mathrm{F})$.

$$
N P C l=B / F
$$

If the value of NPCl is less than one, it provides a positive protection to farmers through input subsidies, when it is greater than one this implies that inputs are taxed by the governments (Atif, 1999).

\section{Effective protection coefficient (EPC)}

The EPC is an incentive measure that measures the protection, according to the value added rather than the final product (Naylor and Gotsch, 1989). The EPC is a useful indicator that measures the whole structure of incentives and dis-incentives which may exist with respect to a given production process and divergences in outputs (in private and social prices) and their similar tradable inputs costs (Gregory, 1995). The EPC can be calculated as:

$$
E P C=(A-B) /(E-F)
$$

When EPC is less than one it indicates negative effects of a policy, disincentives and taxation's in the system. If it is greater than one, it indicates positive effects of a policy (incentives and subsidies in the system) and provides positive incentives to continue producing the commodity. (Atif, 1999).

\section{Domestic resource coefficient (DRC)}

The DRC assesses the social returns to domestic resources or social profits. Usually it measures the efficiency or comparative advantage and determines the efficient use of domestic resources (Gregory, 1995). DRC is calculated as

$$
D R C=G /(E-F) \text {. }
$$

When it is less than one, it shows that the country has a comparative advantage in producing a commodity, while, if it is higher than one, this indicates, the DRC value of domestic resources which is used to produce the commodity is higher than the contribution of its value added at a social price (Tawfic, 1997).

\section{Private cost ratio (PCR)}

PCR represents the private cost of domestic resources $(C)$ that required to produce a unit of a value added, The PCR can be computed by the below equation;

$$
P C R=C /(A-B)
$$

This ratio demonstrates the ability the of the production system to cover the domestic factor cost and continue to be competitive. It is also aproxy for a processing degree within the domestic economy. This ratio is important for investors to optimize their profits by minimizing the costs of tradable inputs and other factors. PCR and DRC ratios compare private and social profitability with respect to use of domestic resources (Gregory, 1995).

\section{Subsidy (or tax) ratio of producers (SRP)}




\section{Sudan in 2003 and 2009}

The subsidy (or tax) Ratio to producers SRP measures the profits proportion of the total social value of the output system to the revenues of outputs at social prices (E).It can be expressed as below:

$$
S R P=L / E
$$

\section{Estimating the shadow exchange rate factor and the standard conversion factor}

The shadow exchange rate SER is the economic price of foreign currency. There is a common misconception that if the market for foreign exchange is a free float, the shadow exchange rate (SER) is equal to the market exchange rate. That would be the case only if there were no taxes and subsidies on the demand and supply of tradable goods, if all commodities and factors priced at their economic value, and if the current account deficit was sustainable. In all cases, the (SER) will diverge from the market or official exchange rate (OER). In general, the greater the divergence between the OER and the SER, the more likely will depreciation or appreciation occur and affect project performance.

Market prices adjusted to economic values, by using accounting prices, more commonly referred to as shadow prices. Shadow prices introduced to reflect the true economic cost of inputs and output to the society in order to give emphasis to contribute to the government's efforts to achieve national development objectives. Shadow prices of goods or services, also known as National Economic Parameters, is thus a measure of the real worth to the economy of a specific resource. This method of shadow pricing is tedious, time consuming, and consequently rarely followed. Instead, non-traded goods are generally valued at economic prices by the use of conversion factors. A conversion factor is a shortcut method for converting prices of nontraded goods and services into border prices. At the most aggregated level a single conversion factor, the standard conversion factor (SCF) can be derived by taking the ratio of all exports and imports at the border price to their value at domestic prices. Shadow prices of non-traded items can obtain by multiplying the (SCF) with the market prices. This reduces market prices to their real economic value. The formula for the SCF is:

$$
M+X
$$

$$
S C F=\frac{}{(M+D)+(X-T)}
$$

Where:

$M=$ value of imports at border prices.

$X=$ value of exports at border prices.

$\mathrm{D}=$ total import duties.

$\mathrm{T}=$ total export taxes.

This approach of converting the financial market value of non-traded goods and services to economic values considered the weakest link in the logical chain of establishing shadow prices. Many applied studies therefore treat non-traded goods and services very approximately (Ministry of Finance, 2003). The (SCF) will generally be less than one, for economic analysis using the world price enumerative, it could be applied to all project items valued at their domestic market price values to convert them to a border prices equivalent value. While items valued at their border price equivalent value left unadjusted. Conversion factors can be calculated and used when testing the economic viability of a project. A conversion factor is the ratio between the economic price value and financial value in project output or input. This ratio can be applied to the constant price values in project analysis to derive the corresponding economic values (Lyn Squire et al 1975). The factor used in this study is 0.98 (Babiker, 2009).

\section{RESULTS AND DISSCUTIONS}

\section{Policy analysis matrix indicators interpreta- tions}

Tables (2 and 3) represent PP and SP (SDG per feddan) of vegetable and fruit crops produced in 2003 and 2009, in the base year 2003, the representative vegetable and fruit systems were very profitable, onion and banana were the most profitable fruit crops. where in 2009 the private profitabilities were less than in 2003. Although SP were positive, but were less than PP except for onion 2009 an for date 2009. Additionally, large negative transfers were gained 2009 for all vegetables except onion and date, however, this result indicating that the government policies were not providing support to vegetable and fruit production systems. As social profit abilities were positive, the system could have operated profitably without government 
policy implementation. The government policies provide support to banana and date in 2009.

Table 2. Private and social profits for vegetable crops in Sudan in 2003 and 2009

\begin{tabular}{|ccccccccc|}
\hline Crops & \multicolumn{2}{c}{ Onion } & \multicolumn{2}{c}{ Green beans } & \multicolumn{2}{c|}{ Melon } & \multicolumn{3}{c|}{ Okra } \\
\hline Years & 2003 & 2009 & 2003 & 2009 & 2003 & 2009 & 2003 & 2009 \\
PP & 2446 & 1763 & 2356 & 2141 & 2109 & 1718 & 1339 & 1603 \\
SP & 2464 & 1588 & 3347 & 3221 & 2491 & 3440 & 4069 & 4586 \\
Transfers & -18 & +175 & -991 & -980 & -382 & -1722 & -2730 & -2980 \\
\hline
\end{tabular}

Source: Author's calculation from PAM budgets (2013)

Table 3. Private and social profits for fruit crops in Sudan in 2003 and 2009

\begin{tabular}{|c|c|c|c|c|c|c|c|c|}
\hline \multirow{2}{*}{$\begin{array}{l}\text { Crops } \\
\text { Years }\end{array}$} & \multicolumn{2}{|c|}{ Mango } & \multicolumn{2}{|c|}{ Banana } & \multicolumn{2}{|c|}{ Date } & \multicolumn{2}{|c|}{ Lemon } \\
\hline & 2003 & 2009 & 2003 & 2009 & 2003 & 2009 & 2003 & 2009 \\
\hline PP & 1447 & 0566 & 1919 & 1548 & 0950 & 1743 & 1207 & 1319 \\
\hline SP & 2841 & 1762 & 1972 & 2698 & 1570 & 1738 & 2702 & 2159 \\
\hline Transfers & -1394 & -1196 & -53 & -1150 & -620 & +5 & -1495 & -840 \\
\hline
\end{tabular}

Source: Author's calculation from PAM budgets (2013)

\section{Nominal protection coefficients on outputs (NPCO)}

The first findings come from the conventional PAM analysis shows that NPCO on the selected vegetable and fruit crops under the study in 2003 and 2009 were less than unity, suggests that outputs of the selected vegetable and fruit crops were taxed either because of market failures or government intervention (as shown in Tables 4 and 5) extended on vegetables in 2003 and 2009, between $10 \%$ and $7 \%$ for onion to $47 \%$ and $44 \%$ on okra, averaging about $26 \%$ and $24 \%$ of the social vegetable prices in 2003 and 2009 ,respectively. While, among fruits, in 2003 and 2009 ranged between $13 \%$ and $3 \%$ for date to $26 \%$ and $33 \%$ on banana, respectively, averaging about $20 \%$ and $23 \%$ of the social fruit prices in 2003 and 2009, respectively. Hence, the government taxes increased on vegetable crops from $24 \%$ in 2003 to $26 \%$ in 2009 , While it increased among fruit crops from $20 \%$ in 2003 to $23 \%$ in 2009 . Indicating that policies cause output prices to be less than that would have been if world prices had been allowed to set domestic prices, indicates that the output policy lowers profits per feddan.

\section{Nominal protection coefficient on inputs (NPCl)}

As shown in Tables (4 and 5), most of the NPI results were over $90 \%$ in 2003 and 2009 except Banana which of about $50 \%$.showing that costs of tradable inputs were less than what would have been at world prices and input policy reduces input costs, that is the input costs were lower by policy, each NPI in both tables, is less than one, that indicating an appearance of lower government subsidies on the input costs (most of them between $2 \%$ to $7 \%$ ). In general, ranging between $2 \%$ on mango to $51 \%$ on banana, averaging about $13 \%$ of the social horticultural prices, while, averaged on vegetable about $10 \%$ and $9 \%$ of the social vegetable prices in 2003 and 2009, respectively, and it averaged about $16 \%$ and $15 \%$ of the social fruit prices in 2003 and 2009, respectively. Thus, the generated increase of government subsidies on 
both vegetable and fruit crops is very weak about (1\%) through 2003 to 2009.

\section{Effective protection coefficient (EPC)}

Various taxations in the whole system of the analyzed exported vegetable crops were ranged between about $6 \%$ and $1 \%$ for onion to $60 \%$ and $55 \%$ for okra during 2003 and 2009, respectively. At the same time, similar taxation of the exported fruits in Sudan is approximately ranged between about 6\%for banana to 28 for lemon in 2003 and $\mathrm{t} 3 \%$ for date and $20 \%$ for Mango in 2009.Based on Tables 4 and 5 the EPC for all horticultural exports is less than unity, indicating a presence of different taxes in the system, which hindering the products production. Accordingly, the extent of efficiency and comparative advantage in producing those crops in 2003 extended between about 6\% for onion and banana to $28 \%$ for lemon and $60 \%$ for okra. While, for vegetables during 2009 , it ranged between about $1 \%$ for onion to $55 \%$ for okra. Also, it ranged for fruit between about 3\% for date to $20 \%$ for mango. Averaging about $31 \%$ and $35 \%$ of the social vegetables prices and about $15 \%$ and $19 \%$ of the social fruits prices during 2003 and 2009 respectively. Thus, this weak efficiency performance of producing horticultural crops, recorded an increase in 2003 and 2009 of about 4\%, because it is more affected by the governmental taxes on the outputs revenues, the net effect of policies that alter prices in product markets is to reduce private profits and the combined transfer effects was negative.

\section{Domestic resource coefficient (DRC)}

Tables (4 and 5) show that DRC is less than unity, that signifying efficiency and solid comparative advantage to continue in producing more horticultural products (privately and socially profitable). This assists in earning sizeable foreign exchange with limited use of domestic resources, despite of the smaller EPC which was affected by the government taxes in the system, it is clear, vegetables efficiency ranged between $74 \%$ for melon and $57 \%$ for onion to $87 \%$ and $83 \%$ for green beans in 2003 and 2009, respectively, exceeding that on fruits, which ranged between $36 \%$ for banana and $27 \%$ for mango to $45 \% \%$ for lemon and $38 \%$ for green beens2003 and 2009, respectively. However, the efficient use of domestic resources had been re- duced from $82 \%$ and $40 \%$ to $73 \%$ and $33 \%$ in 2003 and 2009, respectively.

\section{Private Cost Ratio (PCR)}

The vegetable PCR values were less than unity recorded high private cost of domestic resources to produce a unit of value added, Melon had the highest PCR among fruits in 2003. While, date recorded the largest PCR in 2009. Thus, vegetables efficiency ranged between $83 \%$ for onion and okra) and $61 \%$ for okra to $86 \%$ for melon and $82 \%$ for green beans during 2003 and 2009, respectively. while, it ranged for fruits between $27 \%$ for date and $11 \%$ at mango to $37 \%$ for banana and $33 \%$ for date. That signifying a presence of various positive degrees of efficiencies and competitiveness as policy effect, which is high for vegetables (86\% at Melon in 2003 to $61 \%$ at okra in 2009) and low in fruits (37\% for banana in 2003 to $11 \%$ for mango in 2009). However, the ratio demonstrates the production system's ability to cover the domestic factor cost and continue to be competitive. It is also a proxy for a processing degree within the domestic economy. It assists in optimizing the investor profits by minimizing tradable and domestic costs, particularly in vegetables more than in fruits. It can be said, each PCR or DRC compares private and social profits with respect to use of domestic resources. However, the average efficient use of private cost of domestic resources in vegetable and fruit declined from $84 \%$ and $30 \%$ to $69 \%$ and $24 \%$ during 2003 and 2009, respectively.

\section{Subsidy (or tax) ratio of producers (SRP)}

The results, recorded show that the SRP of all horticultural crops was less than unity and slight negative results (which are almost reverting to zero), indicating that the ratio of the profits transfer in the total social (efficient) value of the system output $(\mathrm{L} / \mathrm{E})$ is very weak, that can be ignored, because the obtained actual profits are too little, for a large production costs, additionally to the weak productivity and production, which caused by the insufficient input intensity level for horticultural crops, inefficient marketing system and weakness of the available infrastructures. the negative values of SRP indicates an overall transfer from producer to society and taxpayers. Tables (4 and 5) show that SRP values were negative except for onion in 
2003and date in2009, indicates presence of taxes on fruit and vegetable producers equal to SRP.

Table 4. Relative measures for vegetable crops in Sudan in 2003 and 2009

\begin{tabular}{|c|c|c|c|c|c|c|c|c|}
\hline \multirow{2}{*}{$\frac{\text { Crops }}{\text { Years }}$} & \multicolumn{2}{|c|}{ Onion } & \multicolumn{2}{|c|}{ Green beans } & \multicolumn{2}{|c|}{ Melon } & \multicolumn{2}{|c|}{ Okra } \\
\hline & 2003 & 2009 & 2003 & 2009 & 2003 & 2009 & 2003 & 2009 \\
\hline NPCO & 0.90 & 0.93 & 0.77 & 0.76 & 0.78 & 0.78 & 0.53 & 0.56 \\
\hline NPI & 0.79 & 0.82 & 0.94 & 0.95 & 0.93 & 0.94 & 0.95 & 0.94 \\
\hline EPC & 0.94 & 0.99 & 0.71 & 0.74 & 0.72 & 0.72 & 0.40 & 0.45 \\
\hline DRC & 0.22 & 0.43 & 0.13 & 0.17 & 0.26 & 0.29 & 0.17 & 0.21 \\
\hline PCR & 0.17 & 0.37 & 0.15 & 0.18 & 0.14 & 0.29 & 0.17 & 0.39 \\
\hline SRP & -4.2 & +0.04 & -0.19 & -0.2 & -0.1 & -0.4 & -0.42 & -0.4 \\
\hline
\end{tabular}

Source: Author's calculation from PAM budgets (2013).

Table 5. Relative measures for fruits in Sudan 2003 and 2009

\begin{tabular}{|c|c|c|c|c|c|c|c|c|}
\hline \multirow{2}{*}{$\frac{\text { Crops }}{\text { Years }}$} & \multicolumn{2}{|c|}{ Mango } & \multicolumn{2}{|c|}{ Banana } & \multicolumn{2}{|c|}{ Date } & \multicolumn{2}{|c|}{ Lemon } \\
\hline & 2003 & 2009 & 2003 & 2009 & 2003 & 2009 & 2003 & 2009 \\
\hline NPCO & 0.98 & 0.98 & 0.49 & 0.51 & 0.95 & 0.96 & 0.94 & 0.95 \\
\hline NPI & 0.84 & 0.86 & 0.74 & 0.67 & 0.87 & 0.97 & 0.77 & 0.87 \\
\hline EPC & 0.77 & 0.80 & 0.94 & 0.81 & 0.83 & 0.97 & 0.72 & 0.83 \\
\hline DRC & 0.57 & 0.73 & 0.64 & 0.62 & 0.63 & 0.68 & 0.55 & 0.65 \\
\hline PCR & 0.72 & 0.89 & 0.63 & 0.73 & 0.73 & 0.67 & 0.72 & 0.74 \\
\hline SRP & -0.15 & -0.2 & -5.5 & -0.9 & -0.1 & +5 & -0.18 & -0.1 \\
\hline
\end{tabular}

Source: Author's calculation from PAM budgets (2013).

\section{Sensitivity analysis}

Due to the static nature of the Policy Analysis Matrix, sensitivity analysis was carried out Following Nguyen \& Heidhues, (2004) and ManeKapaj, Kapaj, Chan-Halbrendt \& Totojani, 2010) approach to determine earning capacity of the investment due to changes in factors such as domestic price, exchange rate, and FOB price. Sensitivity analysis provides a way of assessing the impact of changes in the main parameters on both private and social profitability (Monke \& Pearson 1989). The sensitivity analysis illustrates the reaction in the policy indicators such as NPC, DRC,
EPC and SRP due to changes in the aforementioned factors. Three conditions were evaluated:

1. An increase of $25 \%$ and $50 \%$ in domestic price of vegatable and fruit crops and vice versa.

2. An increase of $20 \%$ in world price (FOB) of vegatable and fruit crops and vice versa.

3. An increase of $20 \%$ in exchange rate and vice versa.

The sensitivity analysis showed the effect of changes in vegetable and fruit crops outputs pri ces by $25 \%$ and $50 \%$ on vegetable and fruit crops returns, other factors remaining constant as shown in Table (6) fruit private profits increase by (94 or $188 \%-158$ or $316 \%$ ) the increase is more obvious in fruits than in vegetables (39 or $78 \%-65$ or 

Sudan in 2003 and 2009

$130 \%$ ), However, on fruit side, date obtained a high expansion, followed by mango, lemon and

Table 6. Sensitivity Analysis for vegetable and fruit crops, Sudan, Ls, 2003

\begin{tabular}{|c|c|c|c|c|c|c|c|c|}
\hline Items & Onion & G. beans & Melon & Okra & Mango & Banana & Date & Lemon \\
\hline Base value PP * & 2446 & 2356 & 2109 & 1339 & 1447 & 1919 & 950 & 1207 \\
\hline $\begin{array}{l}\text { Generated PP, from } \\
+25 \% \text { of outputs }\end{array}$ & $\begin{array}{l}3409 \\
(39 \%)\end{array}$ & $\begin{array}{l}3356 \\
(42 \%)\end{array}$ & $\begin{array}{l}2999 \\
(42 \%)\end{array}$ & $\begin{array}{l}2214 \\
(65 \%)\end{array}$ & $\begin{array}{c}3460 \\
(139 \%)\end{array}$ & $\begin{array}{l}3719 \\
(94 \%)\end{array}$ & $\begin{array}{c}2450 \\
(158 \%)\end{array}$ & $\begin{array}{c}2782 \\
(130 \%)\end{array}$ \\
\hline $\begin{array}{l}\text { Generated PP, from } \\
+50 \% \text { of outputs }\end{array}$ & $\begin{array}{l}4371 \\
(78 \%)\end{array}$ & $\begin{array}{l}4356 \\
(84 \%)\end{array}$ & $\begin{array}{l}3888 \\
(84 \%)\end{array}$ & $\begin{array}{c}3089 \\
(130 \%)\end{array}$ & $\begin{array}{c}5472 \\
(278 \%)\end{array}$ & $\begin{array}{c}5519 \\
(188 \%)\end{array}$ & $\begin{array}{c}3950 \\
(316 \%)\end{array}$ & $\begin{array}{c}4357 \\
(260 \%)\end{array}$ \\
\hline $\begin{array}{l}\text { Generated PP, from - } \\
25 \% \text { of t. inputs \# }\end{array}$ & $\begin{array}{l}2668 \\
(9 \%)\end{array}$ & $\begin{array}{l}2663 \\
(13 \%)\end{array}$ & $\begin{array}{l}2383 \\
(13 \%)\end{array}$ & $\begin{array}{l}1720 \\
(28 \%)\end{array}$ & $\begin{array}{l}2188 \\
(51 \%)\end{array}$ & $\begin{array}{l}2439 \\
(27 \%)\end{array}$ & $\begin{array}{l}1575 \\
(65 \%)\end{array}$ & $\begin{array}{l}1690 \\
(40 \%)\end{array}$ \\
\hline $\begin{array}{l}\text { Generated PP, from - } \\
50 \% \text { of } t \text {.inputs \# }\end{array}$ & $\begin{array}{l}2890 \\
(18 \%)\end{array}$ & $\begin{array}{l}2970 \\
(26 \%)\end{array}$ & $\begin{array}{l}2657 \\
(26 \%)\end{array}$ & $\begin{array}{l}2079 \\
(56 \%)\end{array}$ & $\begin{array}{c}2929 \\
(102 \%)\end{array}$ & $\begin{array}{l}2960 \\
(54 \%)\end{array}$ & $\begin{array}{c}2200 \\
(130 \%)\end{array}$ & $\begin{array}{l}2174 \\
(80 \%)\end{array}$ \\
\hline
\end{tabular}

Source: Results of own calculations, based on appendix (9.4.1-9.4.8).

Note: $\mathrm{PP}^{\star}=$ Private profitability; t. inputs \# = tradable inputs

is gained by okra, both of green beans and melon and onion, respectively (Table 6). Vegetable and fruit crops appear to be more profitable with increase and reduct in of the outputs and tradable inputs prices.

\section{Conclusions and policy implications}

This paper has attempted to analyze the impact of government policies on production of vegetables and fruits in Sudan. The analysis indicated that the adopted policies had a negative impact on the production of vegetables and fruit crops in seasons 2003 and 2009 and the horticultural production and producers had subjected to taxes. There is, in fact, a room for much improvement through an intensification of the production, if the discouraged adopted polices (output taxes), that hinder the producers to utilise their resources fully, is revised and reevaluated. The main implication that can be drowned from the study results is that, Sudan has a comparative advantage in horticultural crops production and there is a possibility for exports promotion programs.

\section{REFRERENCES}

Ahmed, W.M. 2000. The growth in Sudanese horticultural exports. M.Sc. Dissertation, University of Gezira, Wad Medani, Sudan.

ALnagarbi, E.E.M. 1997. The Impact of Privatization on The Gezira Scheme. Unpublished. M.Sc. Dissertation, University of Gezira, Wad Medani, Sudan.

AOAD. Arab Organization For Agricultural Development. 1992-2005. Year book for Agricultural Statistics . Volumes (12-25), Khartoum, Sudan (in Arabic).

Atif, A.K. 1999. Lebanon's agricultural potential: a policy analysis matrix approach. McMaster university and econometric research limited (in Arabic). p.12.

Babiker, N.O. 2009. Impact Analysis of the Government Policies on the Production of Cotton, Sorghum and Groundnut in New Halfa Agricultural Production Corporation (2006- 2010) Unpublished M.Sc. Dissertation, University of Gezira. 
Elamin, A.E.M. 1999. Economics and prospects of potato exports in the Sudan. Ph.D. Thesis. University of Gezira, Wad Medani, Sudan.

Eldaw, A.M. 1999. Sudanese Agriculture, 19901997, policies, production trends and international competitiveness. Berlin, Germany. p. 14.

Elsaied, S.S.A. 2000. Agriculture and Globalization. Second edition, Strategic studies center, Khartoum, Sudan (in Arabic).

FAO, (Food and Agriculture Organization of the United Nations). 1987. Comparative Advantage of Agricultural Production Systems and its Policy Implications in Pakistan. Economic and Social Development Paper (68), Rome.

Gregory, J. Scott 1995. Prices, Products, People. Analyzing Agricultural Markets in Developing Countries. London, England.

Jansen, M. 1986. Comparisons among seed potato sources for the Sudan. In: potato development in the Sudan. Proceedings of asymposion held in Khartoum. Sudan. National technical committee and the potato development project. p. 152.

Lyn, S. 1975. Economic Analysis of Projects. John Hopkins University Press, 1975-XI -153. Retrieved from: www.Press.jhu.edu.

Ministry of Finance. 2003. Different reports.

Naylor, R. and Gotsch, C. 1989. Agricultural Policy Analysis Course-Computer Exercises. Food Research Institute, Stanford University, Palo Alto, CA, USA.

Pearson, S.R. and Monke, E.A 1989. The policy analysis matrix for agricultural development. Ithaca, NY, USA.Corenell University Press.

Tawfic, J. 1997. The agricultural sector in Lebanon: analysis and prospects. (Beirut, Lebanese Policy Centre). p. 20. 